This item was submitted to Loughborough's Research Repository by the author.

Items in Figshare are protected by copyright, with all rights reserved, unless otherwise indicated.

\title{
The UK Independence Party, populism and the British news media: competition, collaboration or containment?
}

PLEASE CITE THE PUBLISHED VERSION

http://dx.doi.org/10.1177/0267323115612215

\section{PUBLISHER}

SAGE (@ the authors)

VERSION

AM (Accepted Manuscript)

\section{PUBLISHER STATEMENT}

This work is made available according to the conditions of the Creative Commons Attribution-NonCommercialNoDerivatives 4.0 International (CC BY-NC-ND 4.0) licence. Full details of this licence are available at: https://creativecommons.org/licenses/by-nc-nd/4.0/

\section{LICENCE}

CC BY-NC-ND 4.0

\section{REPOSITORY RECORD}

Deacon, David, and Dominic Wring. 2019. "The UK Independence Party, Populism and the British News Media: Competition, Collaboration or Containment?”. figshare. https://hdl.handle.net/2134/21442. 
The UK Independence Party, Populism and the British News Media: Competition, Collaboration or Containment?

David Deacon

Professor of Communication and Media Analysis, Department of Social Sciences, Loughborough University, Loughborough, Leicestershire LE11 3TU.

d.n.deacon@lboro.ac.uk

Dominic Wring

Reader in Political Communication, Department of Social Sciences, Loughborough University, Loughborough, Leicestershire LE11 3TU.

d.j.wring@lboro.ac.uk 


\begin{abstract}
This article examines the rise of the UK Independence Party in Britain, and how this 'revolution' has been reported by mainstream news organisations. As a case study of the media and populism, UKIP's rise tends to confound rather than confirm some of the patterns and trends found in previous studies. There is little evidence that 'media logic' has worked to the party's advantage and the recent increase in the intensity of media coverage of UKIP is principally explained by the 'political logic' of its continued electoral advances, changes in communication policy, and a reorientation in the public relations strategies of the party and its opponents.
\end{abstract}

\title{
Introduction
}

Populism has been likened to a 'spectre' that is haunting representative democracies, not least within the European Union (e.g. Schedler, 1996, Albertazzi and McDonnell, 2008). The European parliamentary elections of 2014 showed this now constitutes a severe poltergeist disturbance. Across many nations, populist insurgent parties made extraordinary electoral gains. Most notably, the Front Nationale in France, the UK Independence Party in the UK, the Syriza party in Greece and the Danish People's Party in Denmark all received the highest number of votes from their respective electorates. With the latter two cases, these successes subsequently translated into remarkable national electoral advances, with Syriza elected as leaders of a new ruling coalition in January 2015 and the DPP becoming the second largest party in Denmark in June 2015. 
'Populism' is an imprecise and contested term, not least because it is rarely used for self-reference by those labelled as populists. In this discussion, we concur with those who emphasise populism is not necessarily the preserve of the right wing, nor is it always extremist in character (indeed one of the notable features of much neo-populism is its wish to convey an aura of respectability and restraint). What defines it is an ideological bifurcation that contrasts 'the people' against 'a set of elites and 'dangerous "others" who are together depicted as depriving (or attempting to deprive) the sovereign people of their rights, values, prosperity, identity and voice' (Albertazzi and McDonnell, 2008: 3). The contemporary potency of this ideology has been strengthened by the pressures of globalisation, economic recession, the increased power of supranational agencies and growing public disillusionment with mainstream politics. Certainly, the rampant successes of populist anti-EU parties in 2014 cannot be seen as a minor quibble about subsidiarity, but rather a cri de ceour about perceived threats to national identities and independence.

This article examines the United Kingdom Independence Party (UKIPand begins by examining how what started as a niche party in 1993 focused on securing the UK's exit from the EU developed a broader political narrative, gained considerable electoral momentum and injected a potent brand of libertarian populism into the British political mainstream. The article then examines how the national news media in the UK have reported and represented this insurgent force, and the extent to which these terms of reference have changed over time as the party's campaigning and communication strategies have evolved.

To date, UKIP's relations with the media have attracted some comment, but little systematic analysis. This is surprising because established news organisations are an 
important constituent element of the political mainstream that UKIP is destabilising, and analysis of the media's specific editorial responses to this new party provides insights of wider relevance to debates about media, politics and populism in mature democracies like the UK. For example, it has been claimed that populist movements 'rely heavily on some kind of indirect (and direct) complicity with the mass media' (Mazzoleni, 2003: 6) and that any attempt 'to analyse populism without taking into account... "the media factor" will be severely incomplete’ (Blumler, 2003: xvi). Krämer argues that media populism and populism per se is not necessarily the same thing, and there is a need to be sensitive to the occasions where the media act as 'a substitute or competitor to populism', exist in a state of 'symbiosis or positive feedback' or 'contribute to its containment' (2014: 57). In this analysis, we suggest labelling these responses respectively as 'competition', 'collaboration' and 'containment'. Furthermore, we propose a further distinction between 'passive' containment, where insurgents are confounded by their exclusion from news coverage, and 'active' containment, where journalists editorialize intensively and aggressively against new political entrants.

It is also important to consider how news organisations' responses to populist parties develop over time, as media discourses are always dynamic and 'processual', affected by (and affecting) the evolution of political events and debates (Cottle, 2003: 18). Stewart et al.'s (2003) review of the emergence of new populist political entrants across several international contexts during the 1990s, identified four 'media phases' in their life cycle that correspond to phases in the development of parties themselves. These are: (1) 'ground-laying' (where the media contribute to creating a political environment conducive to the emergence of a new force), (2) 'insurgent' (where media publicity helps the 'early growth' of the new party as it builds its profile), (3) 
'established' (where the party achieves electoral success and becomes a durable presence in the political landscape) and (4) 'decline' (where public support dwindles). According to this model, media responses differ according to their market orientation and the different political and media phases of a party's life cycle. In the ground-laying and insurgency phases, the 'Tabloid media' play a particularly significant role in publicising a new party, engaging 'unhesitatingly' and 'with no moral ambivalence' with its populist issues, discourses and values (2003: 225). In contrast, 'Elite media' tend to ignore the party or mock 'its sensational aspects' (ibid.). During the 'established' phase, tabloid media start to lose interest as the insurgent force loses its novelty and 'power to scandalise' (ibid. 223). In contrast, the growing social importance of the party forces Elite media to take the party seriously, although they retain a degree of ambivalence. In the 'decline phase', elite and tabloid media 'return to the status quo' (ibid.225), ignoring the party as it lessens in public importance and electoral impact. Implicit in this model, is the assumption that different types of news media respond to different 'logics': with Tabloid media, the 'media logic' of drama, conflict and controversy tends to govern their response; whereas with elite media, the 'political logic' of social importance and institutional power are much more central.

Table 1 summarises and synthesises our modifications to the insights provided by Krämer and Stewart et al.: highlighting distinctions between passive and active containment; outlining how one might predict different media will respond to the emergence of a new populist party; and how the importance of their role will vary according to the phases of the party life cycle. One of the purposes of this discussion will be to assess the degree to which the rise of UKIP confirms these trends and, if it does, whether the rise of the party provides a further example of the rise of 'communicalised 
politics' (Blumler, 2003: xvi) in which mainstream media institutions can be seen to play a pivotal role in the (re)definition of the political mainstream.

Table 1: Conceptualising differences in media responses to populist parties

\begin{tabular}{|c|c|c|c|}
\hline & $\begin{array}{l}\text { Ground-laying/ } \\
\text { Insurgent phase }\end{array}$ & Established phase & Decline phase \\
\hline Tabloid media & 'Co-operation' & $\begin{array}{l}\text { Transition towards } \\
\text { 'Passive } \\
\text { containment' }\end{array}$ & $\begin{array}{l}\text { 'Passive } \\
\text { containment' }\end{array}$ \\
\hline $\begin{array}{l}\text { Political } \\
\text { Significance of } \\
\text { Tabloid media }\end{array}$ & High & Modest & Low \\
\hline Elite media & $\begin{array}{l}\text { Mainly 'Passive } \\
\text { containment' } \\
\text { Residual 'Active } \\
\text { containment' }\end{array}$ & $\begin{array}{l}\text { Transition towards } \\
\text { 'Co-operation' } \\
\text { Increase in 'Active } \\
\text { containment' }\end{array}$ & $\begin{array}{l}\text { Mainly 'Passive } \\
\text { containment' } \\
\text { Residual 'Active } \\
\text { containment' }\end{array}$ \\
\hline $\begin{array}{l}\text { Political } \\
\text { Significance of } \\
\text { Elite media }\end{array}$ & Low & High & Low \\
\hline
\end{tabular}

Adapted from Krämer (2014) and Stewart et al. (2003)

As a first step in developing this analysis, it is necessary to provide contextual detail about the historical evolution of UKIP and its changing campaigning and communication strategies. 


\section{The rise of UKIP}

For many years, influential political figures have denied and demeaned UKIP's importance, but this disdain has done little to obstruct significant electoral advances, particularly over the recent period. To date, most of these have been made in so-called 'second order' elections, notably for the European parliament (see Table 1)i. Until 2014, these achievements had not translated into success in parliamentary elections, but two by-election victories delivered the party its first representatives at Westminster. There was considerable speculation that this number would increase to double-figures in the 2015 UK General Election, but in the event only one of UKIP's 624 candidates was elected, even though the party more than quadrupled its vote.

Table 2: UKIP Election performance (1994-2015)

\begin{tabular}{|c|c|c|c|c|c|}
\hline & $\begin{array}{l}1994 \\
\text { European } \\
\text { Election } \\
\text { (GB) }\end{array}$ & $\begin{array}{l}1999 \\
\text { European } \\
\text { Election } \\
\text { (GB) }\end{array}$ & $\begin{array}{l}2004 \\
\text { European } \\
\text { Election } \\
\text { (GB) }\end{array}$ & $\begin{array}{l}2009 \\
\text { European } \\
\text { Election } \\
\text { (GB) }\end{array}$ & $\begin{array}{l}2014 \\
\text { European } \\
\text { Election } \\
\text { (GB) }\end{array}$ \\
\hline Votes & 150,251 & 696,057 & $2,650,768$ & $2,498,226$ & $4,376,635$ \\
\hline Vote share & $1 \%$ & $7 \%$ & $16.1 \%$ & $16.5 \%$ & $26.6 \%$ \\
\hline Elected MEPs & - & 3 & 12 & 13 & 24 \\
\hline \multirow[t]{2}{*}{ Turn out } & $36.8 \%$ & $24 \%$ & $38.2 \%$ & $34.7 \%$ & $35.6 \%$ \\
\hline & $\begin{array}{l}1997 \\
\text { General } \\
\text { Election }\end{array}$ & $\begin{array}{l}2001 \\
\text { General } \\
\text { Election }\end{array}$ & $\begin{array}{l}2005 \\
\text { General } \\
\text { Election }\end{array}$ & $\begin{array}{l}2010 \\
\text { General } \\
\text { Election }\end{array}$ & $\begin{array}{l}2015 \\
\text { General } \\
\text { Election }\end{array}$ \\
\hline
\end{tabular}




\begin{tabular}{|l|l|l|l|l|l|}
\hline & (UK) & (UK) & (UK) & (UK) & (UK) \\
\hline Votes & 105,722 & 390,563 & 605,973 & 919,471 & $3,881,229$ \\
\hline Vote share & $0.3 \%$ & $1.5 \%$ & $2.2 \%$ & $3.1 \%$ & $12.6 \%$ \\
\hline Candidates & 193 & 428 & 496 & 558 & 624 \\
\hline Elected MPs & - & - & - & - & 1 \\
\hline Turn out & 71.3 & $59.4 \%$ & $61.4 \%$ & $65.1 \%$ & $66.1 \%$ \\
\hline
\end{tabular}

There are several reasons for the party's modest performance in national elections thus far, including the rigorous demands of the 'first past the post' system (which necessitates a critical mass of support focused in specific constituencies), historical weaknesses in UKIP's national election strategizing, and the party's uncertain electoral base. The latter has been characterised by Ford et al. (2012) as comprising mainly 'strategic euro-sceptics' and 'polite xenophobes'. The former tend to vote UKIP in less consequential electoral contexts to express their disquiet over Europe, but gravitate back to their main party in national elections. 'Polite xenophobes' on the other hand are the party's core loyalists and support it in all electoral contexts. These voters tend to be less affluent, more disaffected with mainstream politics and are attracted by antiimmigration and anti-establishment rhetoric. Ford and Goodwin have termed these 'the left behind'; a section of society that has been neglected by the main political parties in their battle for middle class swing-voters: 'older, less educated, disadvantaged and economically insecure Britons, who are profoundly uncomfortable in this "new" society which they regard as alien and threatening' (2014). If UKIP is to secure a stronger parliamentary presence it needs to strengthen its connection with this disillusioned and largely untapped electoral constituency, whilst avoiding being characterised as 
extremists and thereby excluding any possibility of retaining strategic Eurosceptic and centre-right support (Lynch and Whitaker, 2012: 295). This is precisely the complex balance the party has been striving to achieve over recent years.

\section{Diversification and Discipline: the Evolving UKIP Strategy}

As noted, UKIP was originally a single issue party fixated with opposing the UK's membership of the EU. Although the party's anti-integrationist stance finds resonance with an increasingly Eurosceptic UK public, the significance of this connection should not be overstated. Polling shows that European integration is of limited and declining significance to electors (Abedi and Lundberg, 2009: 85; Clements et al, 2013) and 'Europe' has become marginalised in the mainstream media agenda since the mid1990s (see Deacon et al., 1998; Deacon and Wring, 2011). In the lead up to the 2010 General Election, UKIP strategists started to appreciate the need to diversify the party's policy portfolio to secure and retain popular support in 'first order' electoral contexts. This diversification strategy created tensions within the party and no little media criticism of the credibility of the manifesto promises made (e.g. Boffey, 2013; Sherman, 2013). But if precise details remain shaky, UKIP's broader strategy became clear in the launch of UKIPs 2010 General Election manifesto, described by a senior party figure as 'the edgiest campaign in history' (Guardian, 14/4/2010: 13). UKIP began by emphasising its anti-establishment credentials thereby connecting with growing public disillusionment with mainstream politicians fuelled by the MP's expenses scandal in 2009 (a theme we label as 'integrity'). This approach was epitomised by one of its main campaign posters that depicted the leaders of the Conservatives, Labour and Liberal Democrat under the headline slogan 'Sod The Lot'. Furthermore, UKIP focused heavily on concerns about immigration policy, presenting a manifesto commitment to introduce 
a five year freeze on immigration and ensuring 'that any future immigration does not exceed 50,000 people per annum'. This foregrounding of integrity and immigration provided UKIP with a far more populist narrative and offered a means for popularising the party's Eurosceptic agenda, by denouncing the EU as an exemplar of nonaccountability, corruption and inefficiency, and as the institution responsible for the alleged 'flooding' of the country by immigrants, particularly from newer member states.

At the same time, the party leadership sought to impose greater professionalism and discipline over its activities. UKIP candidates and members had acquired a considerable reputation over the years for their eccentric, extreme and bigoted pronouncements. For a long time these were tolerated internally as 'going with the territory' of the party's libertarian ethos, revealing the 'individualistic DNA' of UKIP in contradistinction to the dragooned and anodyne professionalism of the mainstream parties (Peev, 2013). These kinds of offensive and infelicitous interventions still occur but now receive censure from the party leadership, because, as Nigel Farage the party's leader put it, UKIP wants to be seen to be 'civilised and grown up' (Guardian, 20/9/2013:12). For example, in September 2013 the party whip was removed from its MEP Godfrey Bloom after he described women at a fringe meeting as 'sluts' and hit a prominent broadcast journalist with the party manifesto after the latter had enquired why the cover had not featured ethnic minority citizens. In January 2014, a UKIP councillor was suspended from the party after he speculated whether serious flooding in England constituted divine retribution for the recent legalisation of gay marriage. The same year, the party introduced a requirement that all potential candidates sign a form confirming they have never had membership of an organisation considered 'liable to bring the party into disrepute', never been convicted of an offence punishable by a 
custodial sentence, and never 'engaged in, advocated or condoned racist, violent, criminal or anti-democratic activity' (Landale, 2014). In December 2014, the party's National Executive Committee introduced strict rules on members' social media activities, prohibiting the use of the UKIP logo without written permission, and threatened suspension for those who 'embarrass' the party. Over the same period there was a significant increase in the party's publicity and campaign expenditure, funded by burgeoning party membership and new financial backers. In 2014, UKIP spent $£ 2.96$ million on its European election campaign, compared with $£ 2.98$ million expenditure by the Conservatives, $£ 1.5$ million by the Liberal Democrats and $£ 1$ million by Labour (Syal, 2014). UKIP also spent considerable amounts of money on its 2015 General Election campaign, indeed, on such a scale, it it has been reported that it 'lost control' of its finances during the election and may need bailing out by a wealthy donor to meet these immediate costs if it is to avoid legal action from the Electoral Commission (Merril, 2015).

These diversification and discipline strategies might seem contradictory; as in presentational and organisational terms, UKIP is seeking to cultivate mainstream respectability, whereas in policy terms, it is promoting and asserting its iconoclastic and populist credentials. However, these tensions are not as irreconcilable as they appear. First, the party is clearly trying to rein-in the extent of its populist turn, for the reasons previously stated, i.e. that 'a radical right strategy' risks needlessly alienating additional centre-right voters. Second, the current parameters of mainstream political discourse in the UK mean UKIP's key messages can no longer be deemed marginal, indeed, a lot of recent policy changes and initiatives can be explained as a direct attempt to undermine UKIP's growing electoral appeal. For example, the Conservative party is now committed 
to an 'in/out' referendum on Europe in 2017 following their reelection in 2015, and in 2014 the Home Office launched a mobile advertising campaign featuring the slogan 'Go Home' targeting illegal immigrants. If that blunt message proved controversial then so did the deployment of the vehicles displaying it to areas traditionally home to nonwhite, legal immigrant communities. Ironically, this particular policy was dismissed as a nasty and unhelpful stunt by Farage who also acknowledged the initiative owed something to his party's growing ability to influence and shape public perceptions and the wider agenda: 'What the billboards should say is please don't vote UKIP, we're doing something' (Groves, 2013). Third, the disciplining of the party has been a necessary step to allow the promotion of its leader, which is a core element in the party's popularization strategy. Until Nigel Farage's second stint at leadership, UKIP lacked the kind of highly visible leader that is typically found within populist parties of this nature (Mazzoleni, 2003: 5) ii. Farage is a highly controversial figure but is by common consent a redoubtable politician, tempering his xenophobic views with an avuncular style intended to cast him as an erudite everyman rather than an ex-merchant banker. It is no accident, for example, that most of his electoral photo-opportunities and journalist briefings are held in public houses with pints of beer in hand. (See Stewart et al [2003:228] for a discussion of the regularity with which the 'manipulation of “ordinariness"' features in neo-populists' media management.) He is also adept at what Ruth Wodak terms 'strategies of provocation' (2014), which are intended to incite media and public comment. For example, in the first televised leadership debate of the 2015 General Election, Farage claimed that $60 \%$ of the 7000 people in the UK diagnosed annually with HIV were foreigners and that each cost the NHS $£ 25,000$ per year. His comments were widely condemned as divisive and offensive, but it seems they formed 
part of what was dubbed a 'shock and awful' electoral strategy by UKIP, designed to reach out to core UKIP support rather than sway floating voters.

The growing electoral potency of UKIP suggests that these new strategies have paid dividends, even if questions remain about the party's durability (the disappointing performance in the 2015 General Election led to the resignation, then 'unresignation' of Farage as UKIP leader and much public discord between leading figures in the party) . But to what extent have the mainstream news media played a part in this reengineering of the political mainstream? Has the UKIP 'revolution' been televised? How have British right-wing newspapers, renowned for their hostility to the EU, immigration and overly professionalized politics, responded to this populist insurgency? It is to these matters that the discussion now turns.

\section{A splash or a ripple?}

Stewart et al. argue that 'any media coverage advances contentious political figures; it enhances their visibility and furthers their ends, by producing some kind of public legitimation' (2003: 236). In their view, this is the most significant matter to consider in terms of the media's role, more important even than how neo-populist parties are presented. To relate this to the categories set out in the introduction, the main challenge for any new party is overcoming 'passive containment'; as 'active containment', where they are subjected to critical editorial treatment, although not desirable, can still work to the party's advantage.

In this section we consider the amount of coverage UKIP has received in first order and second order elections since their inception in 1993. Table 3 shows the relative prominence of UKIP in national media coverage of UK General Elections 
between 2001 and 2010, which could be said to fall within what Stewart et al. (2003) would categorise as an 'insurgent phase' for the party. The results reveal UKIP failed to command any national media prominence across these elections. Even the selfproclaimed 'edgiest campaign in history' in 2010 barely raised a ripple.

Table 3: Prominence of UKIP in UK National General Election Reporting (20012010)

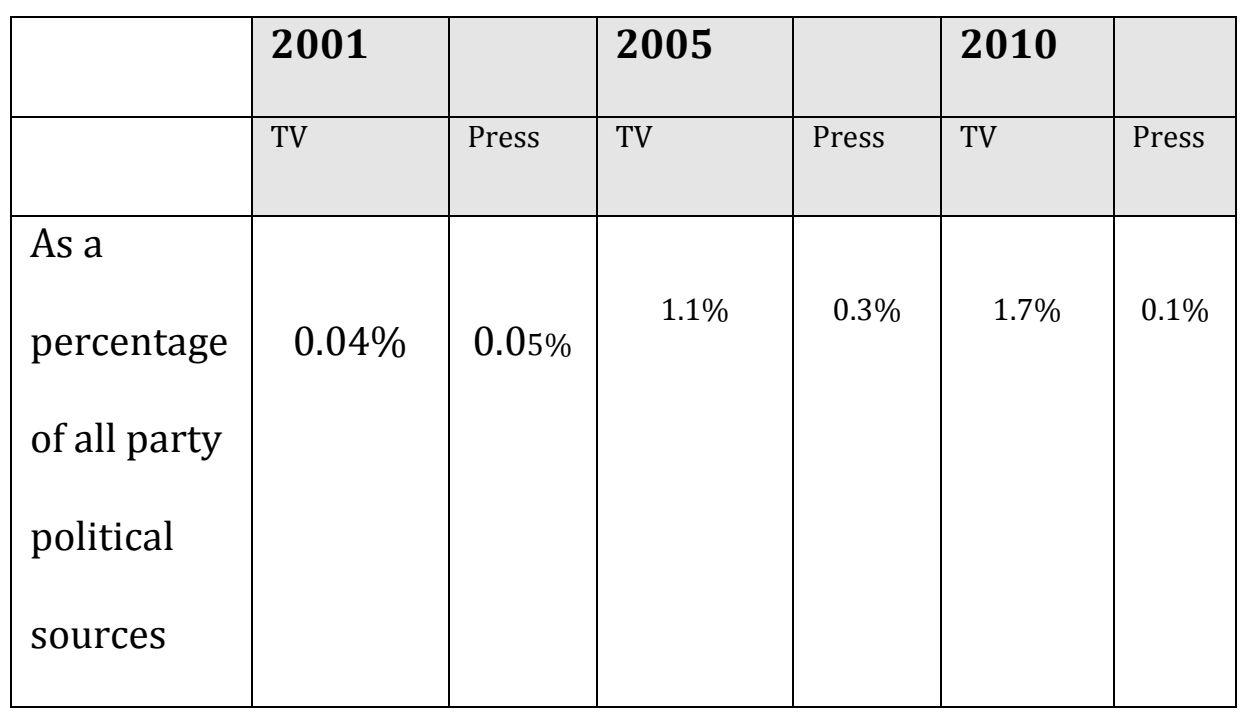

Source: Loughborough Communication Research Centre ${ }^{\mathrm{iii}}$

It should be noted that these figures are based on sampling the most prominent national broadcast and press content during each campaign (see endnote iii), which raises the possibility that UKIP secured greater presence in subsidiary, more expansive domains of national election reporting (such as in Sunday newspapers and additional election supplements). To assess this, we conducted a further content analysis of national press coverage from the 2001 and 2010 General Elections based on a keyword

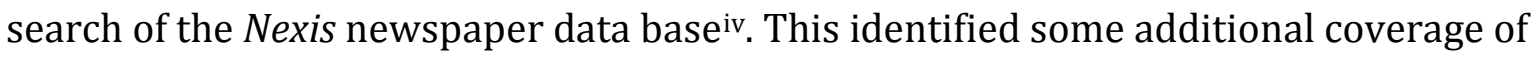
UKIP in the national press in these elections and an increase in 2010 compared with 2001. Nevertheless, levels of national press attention remained modest and were 
mainly located in elite newspapers (see table 4). Further breakdown of these figures shows that the number of 'hard' news reports across both elections did not increase greatly (53 in 2001, 63 in 2010), with most of the expansion in 2010 occurring in the number of 'softer' commentary and feature items. This suggests that any expansion of UKIP's national press election profile in 2010 was in adding 'colour' rather than 'content' to the campaign.

Table 4: Average number of items per edition featuring UKIP in the National Press in 2001 and 2010 General Elections

\begin{tabular}{|l|l|l|}
\hline & 2001 & 2010 \\
\hline & Average number of items & Average number of items \\
& mentioning UKIP per & mentioning UKIP per \\
& edition & edition \\
\hline 'Quality' titles & 0.87 & 1.66 \\
\hline 'Mid-market' titles & 0.28 & 0.94 \\
\hline 'Red Top' titles & 0.12 & 0.20 \\
\hline (Total number of items) & $(123)$ & $(256)$ \\
\hline
\end{tabular}

Notes: 'Quality'=Guardian, Observer, Independent, Independent on Sunday, The Times, Sunday Times, Telegraph, Sunday Telegraph (112 editions); 'mid-market titles' = Mail, Mail on Sunday, Express, Sunday Express (56 editions); 'Red Top' titles = Sun, News of the World, Mirror, Sunday Mirror, the People, the Star (80 editions)

Other research has shown that this marginalization was not restricted to General Election periods. For example, research commissioned by the BBC Trust as part of its investigation of the 'Breadth of Opinion' in the Corporation's coverage examined two month's BBC output from 2007 and 2012. The study found that UKIP's presence in BBC coverage fell between the two sample periods (from 2.7 percent of the party political 
sources featured to 1.4 percent) and this pattern was replicated in commercial broadcast coverage (see Wahl-Jorgenson et al, 2013: 16 and 83).

There is growing evidence that this pattern is changing and that UKIP is starting to secure some significant traction in media terms. For example, we monitored the presence of the party in national newspapers during the last four weeks of the campaign for the 2014 European Parliament. This analysis identified far higher levels of national press attention than in earlier general elections (see table 5). Furthermore, a far higher proportion of this coverage involved news reports (44 percent) and leader editorials (6 percent). An analysis of national broadcast news coverage during the same period found a similar growth in UKIP prominence (Cushion and Sambrook, 2014). Table 5:

Average number of items per edition featuring UKIP in the National Press in the European Elections (25 April-22 May 2014)

\begin{tabular}{|l|l|l|}
\hline & $\begin{array}{l}\text { Average number of items } \\
\text { mentioning UKIP in the } \\
\text { headline }\end{array}$ & $\begin{array}{l}\text { Average number of items } \\
\text { mentioning UKIP anywhere } \\
\text { in the item }\end{array}$ \\
\hline 'Quality' titles & 2.31 & 5.29 \\
\hline 'Mid-market' titles & 1.64 & 3.84 \\
\hline 'Red Top' titles & 1.96 & 3.50 \\
\hline (Total number of items) & $(508)$ & $(1088)$ \\
\hline
\end{tabular}

Notes: 'Quality'=Guardian, Observer, Independent, Independent on Sunday, The Times, Sunday Times, Telegraph, Sunday Telegraph (112 editions); 'mid-market titles' = Mail, Mail on Sunday, Express, Sunday Express (56 editions); 'Red Top' titles = Sun, News of the World, Mirror, Sunday Mirror, the People, the Star (80 editions)

To some extent, this specific increase can be explained by the particularities of the European election period. UKIP has had growing impact in these elections for many 
years, and has always offered journalists a clear and distinctive viewpoint for dramatizing EU campaign coverage. However, this does not provide a sufficient explanation for the increase, as other research shows a significant and sustained recent rise in UKIP's media profile beyond these campaigns. For example, Ford and Goodwin (2014) identified a 290 percent increase in the annual total of UKIP related newspaper items between 2011 and 2013, with the most notable step-change occurring in 2013. In December 2014, The Times newspaper declared Nigel Farage as its 'Briton of the Year', commenting in its leader editorial that 'no one did more to shape British politics in 2014' (The Times, 27/12/2014: 28). In 2015, the Loughborough University Communication Research Centre's General Election news analysis found that UKIP accounted for 9.7\% and $8.3 \%$ of the party political sources reported during the formal campaign in TV and press respectively, and $9 \%$ and $11 \%$ of the direct quotation for all politicians (Deacon et al, 2015).

This change reflects a confluence of factors. The main political parties are increasingly tackling the UKIP threat more directly, rather than ignoring or dismissing the party. In the 2014 European Elections, Nick Clegg, leader of the Liberal Democrats and deputy prime minister, challenged Nigel Farage to debate publicly whether the UK should remain in the EU. This resulted in two live televised debates (one hosted on-line by the radio station 'Leading Britain's Conversation', the other by BBC2), both of which Farage was adjudged to have won, on the basis of audience responses. More surreptitiously, the Conservative party has been conducting a 'below the radar' antiUKIP campaign since at least 2013, collating and publicising to journalists any public statements of UKIP representatives that highlight their intemperance or incompetence. 
The growing intensity of these overt and covert strategies has inevitably drawn greater journalist attention to the insurgent party.

A further significant development is the decision in 2014 by Ofcom, the regulator and competition authority for the UK communications industries, that UKIP should be treated by commercial broadcasters in England and Wales as a 'major party' for the European elections. This official recognition required that UKIP be given equivalent prominence to the other main political parties in news and current affairs programming and an increase in their allocation of Party Election Broadcasts. In January 2015, Ofcom announced this ruling would apply for the 2015 UK General Election, which, aside from guaranteeing the party greater general exposure in this first order election, raised the possibility of Farage's participation in the televised leadership debates, first run in the 2010 election. The prospect of this caused alarm in Conservative circles, compounding their general concern that these broadcasts tend to work to the advantage of opposition parties. Fearing a two-flanked attack from Labour and UKIP, David Cameron insisted he would not participate unless the Green party was was also allowed to appear (Wring and Deacon, 2015). After tortuous negotiations, three televised leadership 'events' were eventually agreed upon: an initial seven way leaders debate (that included Farage and the leaders of the Greens, the Scottish Nationalist Party and Plaid Cymru); a 'challengers debate', which involved Nigel Farage and the leaders of the four other main parties not included in the coalition government; and a final BBC 'question time' special involving the three main political parties and excluding Farage and other challenger parties.

Another factor behind UKIP's heightened media profile is the growing magnanimity of some media owners towards the party, in particular owners of some of the more populist outlets, who have long cherished their 'king-making role' in British 
political life. Of particular significance here is the disposition of Richard Desmond, proprietor of the Daily Express, Sunday Express, Daily Star and Star on Sunday, who donated $£ 300,000$ to UKIP in December 2014 and a further $£ 1$ million during the 2015 General Election. Organizational links between UKIP and Desmond's newspaper titles had been developing for some time ${ }^{v}$ and in the final days of the 2015 General Election led to the Express and Sunday Express formally declaring their support for UKIP (NB the Star newspapers have tended not to declare for a particular party in recent elections, but their coverage in 2015 gave considerable prominence to Farage and his party). Farage has also had several one-to-one meetings with Rupert Murdoch since 2013, suggesting he is beginning to be taken seriously by one of the most influential global media figures, even if, as shall be shown, this has yet to translate into gentle treatment by Murdoch's news organisations (Boffey, 2014).

These recent developments, considered in conjunction with the changing communication strategies of UKIP, raise questions as to whether and to what extent the terms of coverage of the party have changed and whether the recent upswing in media coverage is working to its detriment or advantage. Table 6 relates to the additional analysis of national press coverage of UKIP in the 2001 and 2010 General Election campaigns previously mentioned. For each item, we identified where references were made linking UKIP to questions concerning Europe ('integration'), political propriety and standards ('integrity') and/or 'immigration'. The results show a clear shift in the terms of reference of coverage of the party from 2001, where 'integration' was the sole matter of any note, to 2010 where a growing proportion of items linked the party to questions of 'immigration' and 'integrity' (i.e. where questions about the probity and standards of the mainstream political classes were raised). 
Table 6: UKIP and issues of 'integration', 'immigration' and 'integrity' in UK national press General Election coverage 2001 and 2010

$\begin{array}{lcc} & \begin{array}{c}2001 \\ \text { (Number }\end{array} & \begin{array}{c}2010 \\ \text { of items) }\end{array} \\ & \text { of items) } \\ \text { Integration } & 64 & 67 \\ \text { Immigration } & 4 & 44 \\ \text { Integrity } & 3 & 37\end{array}$

(Notes: the three categories are separate (i.e. individual items could mention 1, 2 or 3 of the topics, or none of them)

For the 2014 European parliament elections we counted which of these matters were signalled in the headlines of articles where UKIP was the main subject or source of an item (508 items in all). The results showed 31\% of the headlines linked UKIP to 'immigration', $3 \%$ to 'integrity' and $6 \%$ to 'Integration'.

On first sight, these findings might suggest that UKIP's strategic repositioning and redefinition of its message has been successful in linking the party to more populist media concerns. But this interpretative fit reveals nothing about how UKIP's connection to these matters was reported. To explore this further, we quantified the frequency with which negative issues related to UKIP were flagged up in newspaper headlines for the last four weeks of the 2014 European parliament elections (see table 7).

Table 7: Issues in UKIP-related headlines for All National Newspapers and Selected Newspapers (25 April-22 May 2014) 


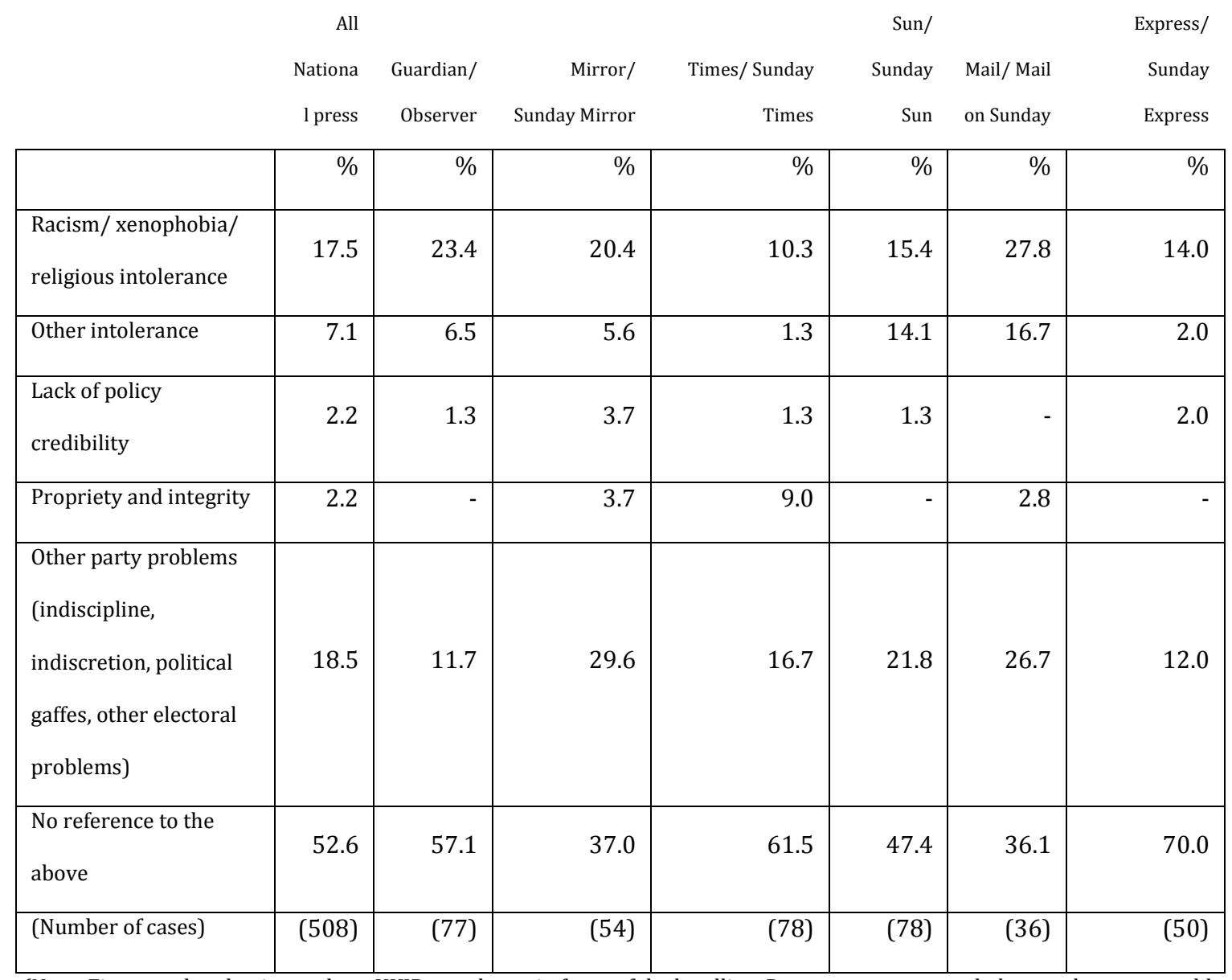

(Note: Figures related to item where UKIP was the main focus of the headline. Percentages are rounded so totals may not add up to 100. 'All National press' category includes titles not listed in the remaining columns: i.e. Daily Telegraph, Sunday Telegraph, Independent, Independent on Sunday, Daily Star \& People. Intercoder reliability: 84 percent agreement, Cohen’s Kappa=0.807)

Overall, the results show that 47.4 percent of all headlines highlighted negative matters regarding UKIP's policies or conduct. A lot of this coverage emphasised the party's electoral gaffes, errors and problems (e.g. 'Nigel skips his own carnival to dodge protests', Daily Mirror, 21/5/2014: 11; 'POPPYCOCK; UKIP election hopeful in huge Uturn over Remembrance Sunday and 9/11 Twitter insults', Sunday Mirror, 27/4/14: 22; 'Ukip's 'British builder' is an EU immigrant', The Independent, 26/4/2014: 10). There was also a substantial discussion of UKIP's racist proclivities, in the main prompted by a series of impolitic comments made by the party leader and other party representatives during the campaign (e.g. 'New Ukip racism row', Guardian, 30/4/2014:2; 'Ukip's Asian poster girl walks out on 'racist' party', Daily Telegraph, 14/5/2014: 6; 'Farage a 'racist' 
in Romania slur row', the Sun, 17/5/2014:2). Several national newspapers dedicated leading articles to this matter. For example, after an unguarded comment from Farage that he would prefer to live next door to Germans rather than Romanians, the Sun commented:

Farage is an affable bloke holding together a party that shares many of The Sun's concerns on Europe but contains more than its fair share of racists and homophobes. .. It is not racist to worry about the impact of millions of migrants on Britain, as we have argued for years. It IS racist to smear Romanians for being Romanian. Nigel Farage, UKIP leader, did just that ('Racism and UKIP', The Sun, 17/5/2014: 7)

A few days later, the Daily Star raised similar concerns in an editorial about a string of PR gaffes that had disrupted the UKIP bandwagon, although avoided directly accusing Farage of racist beliefs:

Mr Farage's straight-talking approach on jobs and barmy human rights laws have (sic) struck a chord with voters. Most agree that Britain must make a stand against the tidal wave of immigration. But he must stamp out the racist element from his party quickly if he wants to be taken seriously ('Clean 'em out Nigel', the Daily Star, 20/5/2014: 6)

What is striking about these editorials, and several others we have identified, is the careful way the leader-writers sought to highlight a distinction between general concerns about immigration levels to the UK and UKIP's approach to the matter. Essentially, the party was accused of raising the 'right' issue in the 'wrong' way. 
Other examples of UKIP intolerance were also frequently reported upon during the 2014 campaign (e.g. Over-70s are not comfortable about gays, says Farage', Express, 12/5/2014:4; 'UKIP plumps for anti-gay', Mirror, 7/5/2014: 2; 'UKIP donor says women cannot be raped in marriage', Guardian, 1/5/2014:18). In contrast, questions about the financial probity and integrity of UKIP representatives, and in particular the party leader, which were circulating during the campaign, only occasionally surfaced in headlines (e.g. UUKIP faces scandal over 'cash for Euro seats', The Times, 14/5/ 2014: 1; 'Farage refuses spending review but admits errors', The Times, 26/4/2014: 7). Similarly, very few headlines highlighted specific concerns about the credibility of the party's manifesto (e.g. 'Osborne: UKIP is a threat to economy; Britain's free market status is at risk for the first time in a generation', Daily Telegraph, 21/5/2014: 1)

Table 4 also compares the editorial responses of a selection of national newspapers, and reveals some noticeable variation between particular titles. Of the elite titles, the pro-EU Guardian \& Observer gave more prominence to UKIP's racism and intolerance than the Euro-sceptic Times and Sunday Times, who in turn gave most coverage of all newspapers to concerns about the propriety and integrity of UKIP representatives. Among the most populist titles, The Sun/Sunday Sun \& the Daily Mirror/Sunday Mirror provided the highest levels of negative copy of all newspapers, with the number of items for the former exceeding those for all other titles. But perhaps the most striking finding from the table is the coverage produced by the Daily Express/ Sunday Express. In these Richard Desmond owned titles, UKIP campaign pratfalls, gaffes and prejudices received signally lower levels of coverage.

\section{Concluding comments}


Media coverage of the rise of UKIP provides an opportunity for considering broader issues and principles concerning the relationship between mainstream media and neo-populist parties. What is most striking is how this case tends to confound rather than confirm claims about the rise of 'communicalised politics' in which the mainstream media occupy a central role. There is no evidence of any significant variation over time between the responses of populist or elite media; in particular, no sign of any cooperation and alignment between the party and the populist media during the so-called 'insurgent phase'. All media inclined to 'passive containment' during this period: ignoring the party in the main and variously patronising them and ridiculing it when they did provide coverage. The considerable increase in media coverage since 2013 has been governed by political logic rather than media logic. UKIP is now newsworthy because its electoral momentum makes it impossible to ignore.

A high proportion of this recent coverage has been very negative, focusing upon the intemperance and incompetence of UKIP representatives. This suggests a new collective media response that should be categorised as 'active containment', but this categorisation requires some qualification. We have shown how UKIP has repositioned its political narrative over the recent period, seeking to exploit concerns about immigration and the integrity of the political classes to advance its anti-integrationist causes. Immigration, in particular, has become a 'hot button' issue for the media in the UK over the recent period (Smith, 2015) and a high proportion of UKIP coverage is now connected to this topic. But even those right wing newspapers that articulate similar concerns about migration levels to the UK, align with more liberal news organisations in presenting much of UKIP's interventions as racist. In this regard, their response can be defined as 'competitive', refusing to allow UKIP to set the terms of this particular 
populist debate. The sole exception to this appears to be the Express group newspapers, which can now be clearly defined as 'collaborative'.

The reluctance of the right wing press to embrace this insurgent party needs to be contextualised within their wider concerns about the damage UKIP's rise may cause the Conservative party, which these papers have realigned with politically over the recent period (Deacon and Wring, 2011). Moreover, the resilience of UKIP support despite trenchant editorial critique challenges traditional assumptions about the power-broking role of national news organisations. Goodwin (2014) argues that this signifies a deep and profound disconnect between the mainstream news media and many sections of UKIP supporters, and that media derision of the party may actually strengthen support for it among people who see the political and media classes as complicit in creating a liberal hegemony that cares little for their concerns and anxieties. This creates a particularly challenging situation for populist news organisations, whose legitimacy, and financial viability, is dependent upon their ability to claim an empathetic connection with 'ordinary people' and their everyday concerns. If the UKIP bandwagon continues to roll, the current disdain of right wing populist media may prove difficult to sustain.

\section{References}

Abedi, Amir \& Thomas Lundberg (2009) 'Doomed to Failure: UKIP and the Organisational Challenges Facing Right-Wing Populist Anti-Political Establishment Parties'. Parliamentary Affairs, 62 (1): 72-87 
Albertazzi, Daniele and Duncan McDonnell (2008) 'The Sceptre and the Spectre' pp. 114 in D. Albertazzi and D.McDonnell (eds) Twenty-First Century Populism, Basingstoke: Palgrave Macmillan.

Bennett, W. Lance (2012) The Personalization of Politics: Political Identity, Social Media, and Changing Patterns of Participation,The Annals of the American Academy of Political and Social Science. 644(1): 20-39

Blumler, Jay (2003) ‘Broadening and Deepening Comparative Research’ pp. xv-xx., in G. Mazzoleni, G., J. Stewart and B. Horsfield (eds) (2003) The Media and Neo-Populism: A Contemporary Comparative Analysis, Westport: Praeger,

Boffey, Daniel (2013) 'Ukip in Chaos Over Policy on Eve of Key Poll, Emails Reveal', The Observer. 27 April, p.1

Boffey, Daniel (2014) 'Nigel Farage in Talks With Rupert Murdoch', the Observer. 7 September, p.4.

Clements, Ben, Philip Lynch and Richard Whitaker (2013) 'The low salience of European integration for British voters means that UKIP will have to expand their platform to gain more support'. LSE European Politics and Policy (EUROPP) Blog Entry, $8^{\text {th }}$ March (accessed, 11 March 2014).

Cottle, Simon (2003) 'News, Public Relations and Power: Mapping the Field' in Simon Cottle (ed), News, Public Relations and Power. London: Sage. 
Deacon, David, Peter Golding and Michael Billig (1998) 'Between Fear and Loathing: National Press Coverage of the 1997 General Election' in D. Denver, J. Fisher, P. Cowley and C. Pattie (eds) British Elections and Parties Review, Volume 8. London: Frank Cass. Deacon, David and Dominic Wring (2011) 'Reporting the 2010 General Election: Old Media, New Media - Old Politics, New Politics' in D. Wring, R.Mortimore, and S. Atkinson (eds) Political Communication in Britain: The Leader's Debates, the Campaign and the Media in the 2010 General Election. Basingstoke: Palgrave Macmillan.

Deacon, David, John Downey, James Stanyer and Dominic Wring (2015) 'News media performance in the 2015 General Election campaign' pp.12-13 in D. Jackson and E. Thorsen (eds) UK Election Analysis 2015: Media, Voters and the Campaign, Bournemouth: Centre for the Study of Journalism, Culture and Community, Bournemouth University.

Ford, Richard, Matthew Goodwin, David Cutts (2012) 'Strategic Eurosceptics and Polite Xenophobes: Support for the United Kingdom Independence Party in the 2009 European Party Elections', European Journal of Political Research, 51: 204-234. Ford, Richard and Matthew Goodwin (2014) Revolt on the Right: Explaining Support for the Radical Right in Britain. London: Routledge.

Goodwin, Matthew (2014) 'Why Ukip's scandals don't seem to be hurting its popularity', the Guardian, 15 December (http://www.theguardian.com/commentisfree/2014/dec/15/ukip-scandalspopularity-voters, accessed 25 Feb 2015) 
Groves, Jason (2013) 'Tory posters telling illegal immigrants to 'Go Home' branded 'nasty' by UKIP's Farage as Lib Dems demand they be 'shredded now', Daily Mail $25^{\text {th }}$ July

Juris, Jeffery (2012) 'Reflections on \#Occupy Everywhere: Social media, public space, and emerging logics of aggregation', American Ethnologist. 39(2): 259-279.

Krämer, Benjamin (2014) ‘Media Populism: A Conceptual Clarification and Some Theses on its Effects', Communication Theory, 24(1): 42-60.

Landale, James (2014) 'UKIP: “No Skeletons in my Cupboard', BBC News, 28 Feb. (http://www.bbc.co.uk/news/uk-politics-26385178, accessed 26 March 2014) Lynch, Philip. and Richard Whitaker (2103) 'Rivalry on the right: The Conservatives, the UK Independence Party (UKIP) and the EU issue', British Politics. 8(3): 285-312 Mazzoleni, Gianpietro. (2003) 'The Media and the Growth of Neo-Populism in Contemporary Democracies' , pp.1-20 in G. Mazzoleni, J. Stewart, and B. Horsfield (eds) (2003) The Media and Neo-Populism: A Contemporary Comparative Analysis. Westport: Praeger.

Merril, Jamie (2015) 'UKIP struggling after “massive” electoral costs', The Independent, 21 June, p.6.

Peev, Gerri. (2013) ‘UKIP chief walks out after only eight months after struggling to adapt to 'individualistic DNA' of the party', Daily Mail, 21 August.

Sherman, Jill (2013) ‘UKIP dream for a better Britain Vanishes into a ‘ $£ 120$ bn Black Hole', The Times. 29 April, p.9. 
Smith, David (2015) Immigration in UK Newspapers during General Election Campaigns, 1918-2010. Unpublished doctoral dissertation, Loughborough: Department of Social Sciences, Loughborough University.

Stewart, Julianne., Gianpietro Mazzoleni, and Bruce Horsfield (2003) 'Power to the Media Managers' pp.217-239 in G. Mazzoleni, J. Stewart, and B. Horsfield (eds) (2003) The Media and Neo-Populism: A Contemporary Comparative Analysis. Westport: Praeger.

Syal, Rajeev (2014) 'UKIP outspent Labour and Lib Dems in European Elections, new figures show', Guardian, 17 December.

Wahl-Jorgensen, K., R. Sambrook, M. Berry, K. Moore, L. Bennett, J. Cable, I. GarciaBlanco, J. Kidd, L. Dencik and A. Hintz (2013) Breadth of opinion in BBC output. Cardiff: Cardiff School of Journalism, Media and Cultural Studies.

(http://downloads.bbc.co.uk/bbctrust/assets/files/pdf/our work/breadth opinion/co ntent analysis.pdf, accessed 1 Feb 2015).

Wring, Dominic and David Deacon (2015) 'Leader debates 2015: don't hold your breath for a repeat of 2010', (http://theconversation.com/leader-debates-2015-dont-holdyour-breath-for-a-repeat-of-2010-36233, accessed 29 Jan 2014).

Wodak, Ruth (2014) 'The strategy of discursive provocation : a discourse-historical analysis of the FPÖ's discriminatory rhetoric', pp. 101-122 in P. Jackson; M. Feldman (eds),Doublespeak: the rhetoric of the far right since 1945, Stuttgart : ibidem-Verlag 
${ }^{\mathrm{i}}$ UKIP has also had some remarkable successes in local government elections, such as the 2013 elections where it secured $23 \%$ of the vote across the seats it contested.

ii Farage became leader of UKIP in September 2006. He resigned in 2009 to focus on campaigning for the Buckingham constituency in the 2010 General Election. He was re-elected as party leader in November 2010.

iii Broadcast samples covered the weekday editions of BBC1 main evening news, BBC2 Newsnight, C4 Evening News, Sky News pm, Channel 5, BBC Radio 4 Today, BBC1 Newsbeat. The press sample covered all weekday editions of national titles' election coverage that appeared on either the front page, the first two pages of the domestic news section, the first two pages of any specialist section assigned to the coverage of the campaign, or the page containing and facing papers' leader editorials

iv The searches used the terms 'UKIP', 'UK Independence Party' and 'United Kingdom Independence Party' and were conducted for the 28 days preceding the 2001 and 2010 ballot day. The corpus of was items was then edited to remove all duplicates and items that had only appeared on-line.

` For example, the Daily Express's ex-political editor, Patrick O'Flynn resigned in 2013 to become a UKIP MEP and the party's Director of Communications; and in October 2014 Lord Stevens, the UKIP peer and former chairman of Express Newspapers, was reappointed as deputy chair of the Express group. 